\title{
The structure and properties of viscoelastic polyurethane foams with fillers from coffee grounds*)
}

\author{
Monika Auguścik-Królikowska ${ }^{1) * *)}$, Joanna Ryszkowska ${ }^{1)}$, Agata Ambroziak ${ }^{1)}$, \\ Leonard Szczepkowski' ${ }^{2)}$, Rafał Oliwa ${ }^{3)}$, Mariusz Oleksy ${ }^{3)}$
}

DOI: dx.doi.org/10.14314/polimery.2020.10.6

\begin{abstract}
The subject of the research presented in this article are viscoelastic polyurethane foams (VPF) made using a fillers from coffee grounds. The foams were made with varying content of coffee fillers. Foams and fillers were characterized by means of techniques such as infrared spectroscopy, thermogravimetric analysis, differential scanning calorimetry and cone calorimeter. The changes in the microstructure of the foams were analyzed using a scanning electron microscope. Foam properties in the compression test was assessed. As a result, it was concluded that the use filler from coffee grounds causes a significant reduction in compression set of foams after compression by $75 \%$ and by $90 \%$ of the height of the samples. It was shown that these changes are caused by changes in the chemical structure of the macromolecules of these foams but also in their structure. After addition the filler, all foams have permanent deformations with a value below the permissible limit of $10 \%$. Addition of $20 \%$ by mass of filler caused by a decrease in the rate of heat release and the rate of smoke release during foam combustion.
\end{abstract}

Keywords: viscoelastic polyurethane foams, waste of coffee, grounds, structure, permanent deformation, hardness.

\section{Struktura i właściwości lepkosprężystych pianek poliuretanowych napełnionych fusami kawy}

Streszczenie: Przedstawiono wyniki badań lepkosprężystych pianek poliuretanowych (VPF) wytworzonych z dodatkiem różnych ilości fusów kawy. Pianki i napełniacz scharakteryzowano z zastosowaniem spektroskopii w podczerwieni, analizy termograwimetrycznej, różnicowej kalorymetrii skaningowej i kalorymetru stożkowego. Zmiany w strukturze pianek obserwowano metodą skaningowej mikroskopii elektronowej. Oceniono właściwości pianek w próbie ściskania. Stwierdzono, że napełniacz w postaci fusów kawy powoduje zmniejszenie odkształcenia trwałego pianek w próbie ściskania o $75 \%$ i zmniejszenie o $90 \%$ wysokości próbek, co jest wynikiem zmian w budowie makrocząsteczek pianek i w ich strukturze. Wprowadzenie $20 \%$ mas. napełniacza spowodowało zmniejszenie szybkości wydzielania ciepła i dymu w trakcie spalania pianek.

Słowa kluczowe: lepkosprężyste pianki poliuretanowe, odpady kawy, fusy, struktura, odkształcenie trwałe, twardość.

Coffee is a very popular drink, which makes it the second largest sold commodity in the world, second only

\footnotetext{
1) Warsaw University of Technology, Faculty of Materials Science, Wołoska 141, 02-507 Warszawa, Poland.

2) FAMPUR Adam Przekurat Company, Gersona 40/30, 85-305 Bydgoszcz, Poland.

3) Rzeszow University of Technology, Faculty of Chemistry, Department of Polymer Composites, al. Powstańców Warszawy 6, 35-959 Rzeszów, Poland.

*) Material contained in this article was presented at the Science and Technology Conference on "Polyurethanes 2019", Ustroń, Poland, 13-16 October 2019.

**) Author for correspondence: monika.auguscik.dokt@pw.edu.pl
}

to crude oil [1, 2]. According to the International Coffee Organization 9.5 million tons of coffee is produced in 2018 , and its production is steadily increasing.

Spent coffee ground (SCG) is the residue obtained during the brewing process [3]. The huge amount of residue arise too in the production of soluble coffee. Annually, around 6 million tons of coffee grounds are produced all over the world.

Currently, SCGs are used for composting, gardening, bioenergy production, mushroom growth. By 2020, more coffee waste is expected to be used for energy production [2]. Lack of proper management of SCGs can lead to environmental pollution [4]. That is why a lot of research is carried out to develop them for example: for biodiesel produc- 
tion [5, 6], as source of sugars [7] and as sorbent for metal ions removal $[8,9]$. Coffee beans contain large amounts of organic compounds (i.e. fatty acids, lignin, cellulose, hemicellulose, and other polysaccharides). This includes a significant amount of carbohydrates, minerals and proteins, as well as caffeine, tannins and free phenols [2, 10, 11]. Some of these compounds are toxic, which limits the possibility of using SCGs as animal feed. In addition, SCGs contain a high moisture content, which significantly hinders their management, due to putrefaction processes [12]

The chemical structure and composition of coffee waste particles is similar to the structure of its beans [13], they are rich in carbohydrates (forming primary structures, i.e. hemicellulose, cellulose, lignin) and so-called secondary structures, i.e. pectins, proteins and bioactive compounds [2]. Literature review revealed that about 40-50 wt \% of SCG is polysaccharides as cellulose and hemicellulose structures [14-17]. Spent coffee ground (SCG) contains: fatty acids, amino acids, polyphenols, minerals and polysaccharides that can be exploited as a source of valueadded products [2]. The SCG were characterized for their moisture content (12.1 wt \%), cellulose (33.6 wt \%) and total lignin (13.8 wt \%) [5].

Various groups of natural fillers: mineral, animal and vegetable origin can be used to produce polymer composites from thermoplastics and duroplasts [18]. In the group of fillers of plant origin, different parts of plants can be used: bast, leaves, seeds, stems, grasses, reeds, husks and shells. Coffee grounds may be included in this group of fillers. When using plant fillers for the production of polyurethanes, it is important that the hydrophilic cellulose contains three hydroxyl groups $(\mathrm{OH})$ easily absorbs moisture, it can also contain carboxyl groups $(\mathrm{COOH})$, the other component hemicellulose contains both $\mathrm{OH}$ and $\mathrm{COOH}$ groups. Both components contain functional groups that can react with isocyanate groups. On the other hand, secondary ingredients may e.g. act as plasticizers. The subject of the article are composites of viscoelastic polyurethane foams modified with a filler obtained from coffee grounds.

Viscoelastic polyurethane foams (VPF), also known as shape memory foams, is characterized by slow recovery after compression [19]. The main application is the high quality mattress and pillow segment, where viscoelastic foams distribute the body weight over a larger area. For several years these foams have been of particular interest in the industry [20, 21].

\section{EXPERIMENTAL PART}

\section{Materials}

The matrix of the composite was viscoelastic foam (VPF), (know how - FAMPUR Adam Przekurat). Foams were produced with the isocyanate index $-I N C O=90$. The following components were used to make the materials:
- polyol Daltocel F442, F526 Huntsman Polyurethanes;

- polyol Rokopol F3600 z PCC Rokita SA, Poland;

- polyol Rokopol M1170 z PCC Rokita SA, Poland;

- isocyanate Ongronat 4040 BorsodChem, Hungary;

- foaming agents, water;

- catalysts;

- surfactants.

As modifiers were used filler from spent coffee grounds - post-consumer grounds of coffee obtained from the Costa Cafe in Warsaw. The dried waste was milled using a coffee grinder. The foams were produced by a one-step method. Polyol component A containing polyols, catalysts, surfactants, water, catalysts, and filler were prepared for the composites. Then, using a stirrer at $3000 \mathrm{rpm}$, component $\mathrm{A}$ was mixed for $10 \mathrm{~s}$, then component A was mixed with component B (isocyanate) for $10 \mathrm{~s}$ and poured into an open rectangular mold. During the synthesis, the start time and foam growth time were recorded. After the synthesis, the foam was heated at $70^{\circ} \mathrm{C}$ for an hour, then seasoned for 7 days at room temperature. Only after this time, test samples were cut. The sample names, the foams' composition are given in Table 1.

T a b l e 1. Description of tested materials

\begin{tabular}{c|c|c|c|c|c}
\hline Sample & VPF0 & VPF10 & VPF20 & VPF30 & VPF40 \\
\hline $\begin{array}{c}\text { Filler content, php - parts per } \\
\text { hundred polyol by weight }\end{array}$ & 0 & 10 & 20 & 30 & 40 \\
\hline
\end{tabular}

\section{Methods of testing}

- The apparent density $(d)$ was calculated by measuring the mass and volume of the sample. The mass of the samples was determined with an accuracy of $\pm 0.001 \mathrm{~g}$, and the dimensions of the samples were measured with an accuracy of $\pm 0.01 \mathrm{~mm}$. The apparent density of foams was determined according to PN-EN ISO 845:2010 standard.

- The chemical composition was analyzed using a Nicolet 6700 (Thermo Electron Corporation) - FT-IR spectrophotometer equipped with an ATR unit (suppressed total reflection). Each sample was scanned 64 times in the $400-4000 \mathrm{~cm}^{-1}$ wavelength range, absorption spectra were recorded. The results were analyzed using OMNIC Spectra 2.0 software (Thermo Nicolet).

- Thermogravimetric analysis was performed using a TGA Q500 TA Instrument under a nitrogen atmosphere. Samples of approximately $10 \mathrm{mg}$ were heated in platinum dishes from room temperature to $700^{\circ} \mathrm{C}$, with a heating rate of $10^{\circ} \mathrm{C} / \mathrm{min}$.

- Differential scanning calorimetry was performed using a DSC Q1000 from TA Instruments. Measurements were made in a helium atmosphere in hermetic aluminum crucibles. Samples of approximately $6 \mathrm{mg}$ were heated from $-80^{\circ} \mathrm{C}$ to $200^{\circ} \mathrm{C}$ with a heating rate of $10^{\circ} \mathrm{C} / \mathrm{min}$.

- A Hitachi SEM TM3000 scanning electron microscope was used to observe the microstructure of the produced materials. Before observation, filler and foam 
samples were sprayed with a palladium gold layer. Observations were made using a $5 \mathrm{keV}$ voltage.

- Compressive set (CS) deformation was determined on $50 \times 50 \times 50\left(\mathrm{~mm}^{3}\right)$ samples in the direction of foam growth. Foams were compressed by $50 \%, 75 \%$ and $90 \%$ of the original height in metal covers. Then they were placed in an oven at $70^{\circ} \mathrm{C}$ for 22 hours. After this time, the samples were removed from the metal covers and after 0.5 hours at room temperature their height was again measured. The percentage loss in height of samples was calculated, thus determining compression set: $\mathrm{CS}\left(22 \mathrm{~h}, 70^{\circ} \mathrm{C}, 50 \%\right), \mathrm{CS}$ $\left(22 \mathrm{~h}, 70^{\circ} \mathrm{C}, 75 \%\right), \mathrm{CS}\left(22 \mathrm{~h}, 70^{\circ} \mathrm{C}, 90 \%\right)$. The test was carried out according to the standard PN-EN ISO 1856:2018-09.

- The foam compression process on the Zwick Z005 testing machine was also assessed. The samples were compressed by $75 \%$ of their height. The value of compressive stresses during loading and unloading was obtained, thus obtaining a hysteresis loop. Each sample was squeezed 4 times. The comfort coefficient (SAG factor) of the foam (stress at $65 \%$ compression of the sample/stress at $25 \%$ height of the sample) and the hardness of the foam (stress at $40 \%$ height of the sample) was determined on the basis of the compression test. The test was carried out according to the standard PN-EN ISO 3386-1:2000.

- Particle size was determined in a Horiba LA-950 laser particle size analyzer using the LALLS (Low Angle Laser Light Scattering) technique to achieve full geometric and morphological characteristics of powders. The measurements were carried out with the refractive index specific to cellulose (1.47) laser setting, which reports the full geometrical and morphological characteristics of powders.

- The foams were also characterized using a cone calorimeter (Fire Testing Technology Ltd.) in accordance with ISO 5660:2002. The samples with the dimensions of $100 \times 100 \times 8\left(\mathrm{~mm}^{3}\right)$ were tested by heat flux at $35 \mathrm{~kW} / \mathrm{m}^{2}$.

\section{RESULTS AND DISCUSSION}

\section{Filler characteristics}

The structure of the filler (SCG) is similar to other plant fillers, which are composed of three main primary com-

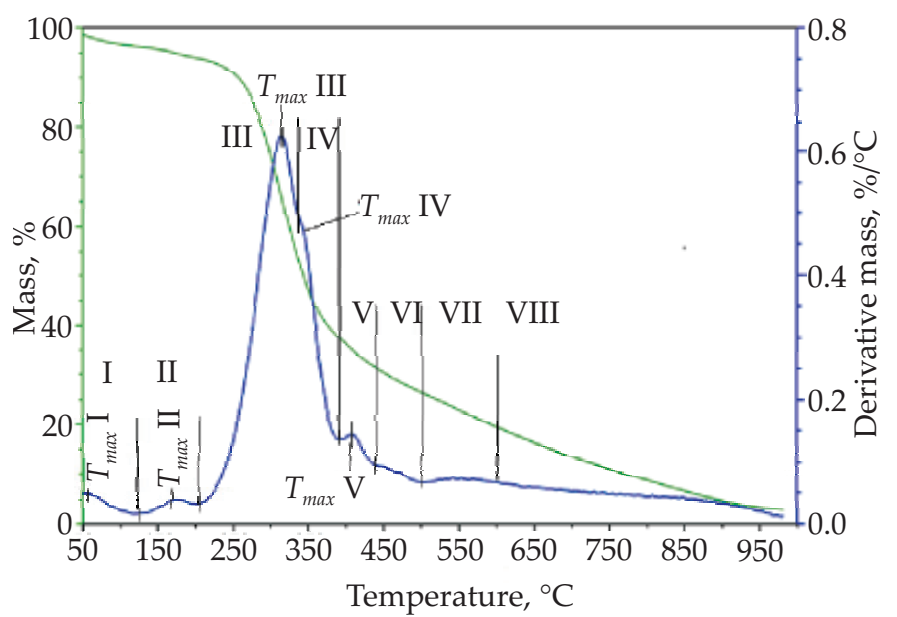

Fig. 1. TGA and DTG curves for SCG

ponents: cellulose, lignin and hemicellulose, and secondary components, i.e. extracts, waxes and others [5]. To describe the structure of the SCGs used, thermogravimetric analysis (TGA) and analysis of the derivative of mass changes as a function of temperature (DTG), differential scanning calorimetry (DSC), chemical structure analysis using Fourier transform infrared spectroscopy (FT-IR) and scanning microscopic observations electron microscopy (SEM). The results of thermogravimetric analysis of SCG are shown in Fig. 1.

VIII degradation stages were observed on the DTG curve. At each stage, the mass loss at a given stage $\left(\Delta m_{i}\right)$ was estimated. For selected degradation stages, the temperature of the maximum degradation rate in a given stage $\left(T_{\max }\right)$ and the degradation rate $\left(v_{\max }\right)$ were determined on the DTG curve. The results of this analysis are summarized in Table 2.

The SCG were dried but total elimination of water was difficult due to the hydrophilic nature of the particles, which is present even as structurally bound water molecules. The first one step up to $120^{\circ} \mathrm{C}$ representing the mass loss in particles could be related to water loss associated with moisture present in the particles [22-24]. The initial stage of the SCGs degradation was associated with loss of about $3.6 \mathrm{wt} \%$ water. Compared to other natural fibers, which may contain up to approx. $15 \mathrm{wt} \%$ is a small

T a b l e 2. Results of TGA and DTG analysis of SCG in subsequent steps of degradation

\begin{tabular}{c|c|c|c|c|c}
\hline $\begin{array}{c}\text { The SCG } \\
\text { degradation stage }\end{array}$ & $\begin{array}{c}\Delta T_{i} \\
{ }^{\circ} \mathrm{C}\end{array}$ & $\begin{array}{c}\Delta m_{i} \\
\mathrm{wt} \%\end{array}$ & $\begin{array}{c}T_{\max } \\
{ }^{\circ} \mathrm{C}\end{array}$ & $\begin{array}{c}v_{\max } \\
\mathrm{wt} \% /{ }^{\circ} \mathrm{C}\end{array}$ & $\begin{array}{c}\text { Description of the SCG } \\
\text { degradation stage }\end{array}$ \\
\hline I & $\leq 120$ & $3.6 \pm 0.5$ & 55 & 0.05 & $\begin{array}{c}\text { Water } \\
\text { Lipids, proteins, caffeine, } \\
\text { II }\end{array}$ \\
tannins or free phenols \\
III & $200-340$ & $1.1 \pm 0.5$ & 175 & 0.04 & 0.63 \\
IV & $340-390$ & $15.5 \pm 0.7$ & 314 & 0.48 & Hemicellulose \\
V & $390-445$ & $6.5 \pm 0.5$ & 410 & 0.14 & Cellulose \\
VI & $445-500$ & $4.7 \pm 0.5$ & 450 & 0.09 & Lignin \\
VII & $500-600$ & $6.9 \pm 0.5$ & 475 & 0.08 & Lignin \\
VIII & $\geq 600$ & $19.5 \pm 1.1$ & & & Lignin and aromatic ring \\
\hline
\end{tabular}




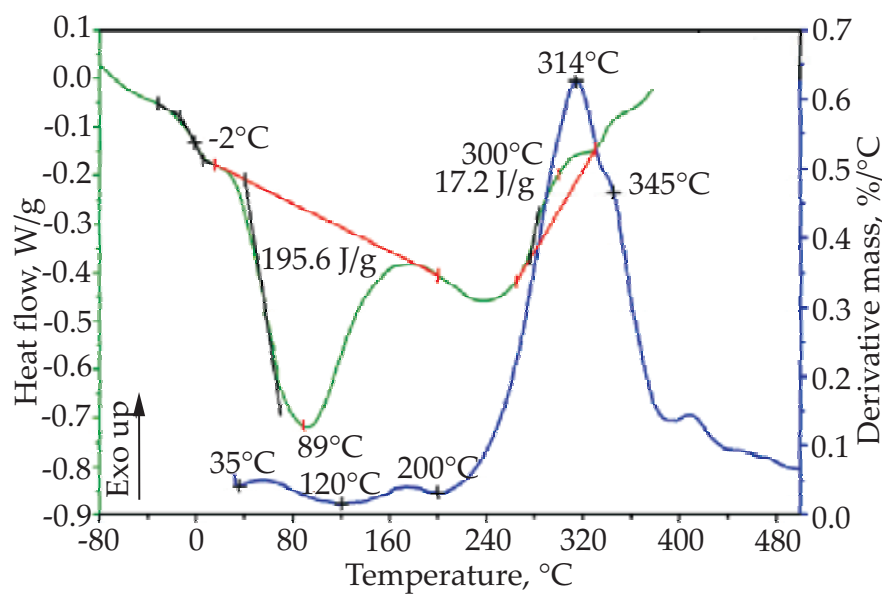

Fig. 2. DSC and DTG thermograms of SCG

amount of water [25]. The maximum degradation rate in this step is reached at $55^{\circ} \mathrm{C}$. The moisture content of the fibers dependent on the content of non-crystalline parts of cellulose and the void content of the particles [26, 27].

Therefore, it can be assumed that during the second stage degraded, bound water in the structure and the socalled second order ingredients: proteins, caffeine, tannins or free phenols. During this stage, about $1.1 \%$ of the sample mass was lost, and the maximum degradation rate at this stage is lower than during the first stage and was achieved at $175^{\circ} \mathrm{C}$.

The subsequent stages of SCG degradation are associated with the degradation of the primary components of vegetable fillers: hemicellulose $\left(200-320^{\circ} \mathrm{C}\right)$, cellulose $\left(250-380^{\circ} \mathrm{C}\right)$ and lignin $\left(280-500^{\circ} \mathrm{C}\right)[28,29]$. During stage III, hemicellulose is degraded, thermal stability of hemicellulose is weaker than that of cellulose, which is attributable to easy ring opening, ring cleavage, dehydration or deacetylation reproducing monosaccharides. The maximum degradation rate at this stage is the highest among all degradation stages and is achieved at a temperature of approx. $315^{\circ} \mathrm{C}$. In the next stage, cellulose decomposes.

Cellulose is ordered and with a long polymer of glucose with a glycosidic bond without branches, although it also turns into low molecular hydrocarbons owing to thermal decomposition [30]. In stages V and VI, lignin is degraded, and in the next stage (VII) degradation products from previous stages are decomposed. About $20 \%$ of residues remain after these processes, of which approx. $12 \mathrm{wt} \%$ is ash [31].

At work, Lina et al. [32] it was found that the share of basic and primary components of SCG are: hemicellulose $39 \pm 2 \mathrm{wt} \%$ of dry SCG, cellulose (glucose) $12 \pm 1 \mathrm{wt} \%$, lig$\operatorname{nin} 24 \pm 2 \mathrm{wt} \%$. In the coffee grounds used for research, the share of basic ingredients determined on the basis of TGA analysis is similar: hemicellulose $42.7 \mathrm{wt} \%$, cellulose $15.5 \mathrm{wt} \%$, lignin $18.2 \mathrm{wt} \%$.

Thermal analysis using TGA was supplemented by analysis using DSC. Figure 2 compares DSC and DTG thermograms. The DSC thermogram shows the thermal transitions of the samples between -80 and $360^{\circ} \mathrm{C}$. The

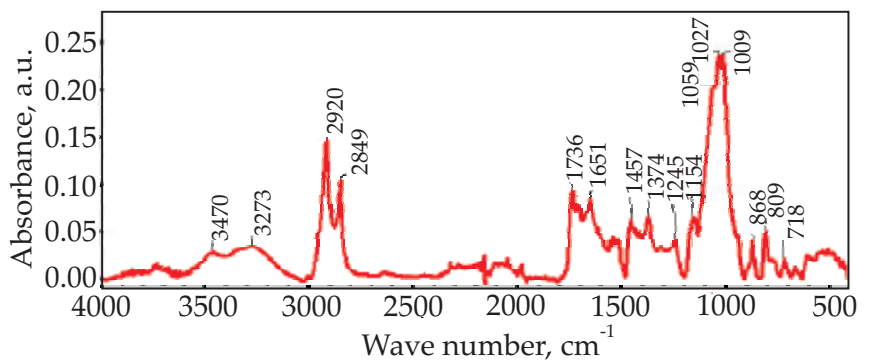

Fig. 3. FT-IR spectra of SCG

thermogram obtained for SCG showed glass transition and two events. For SCG the first event was observed with a peak at $89^{\circ} \mathrm{C}$, and an associated enthalpy change of $195.6 \mathrm{~J} / \mathrm{g}$. This event is related to the melting transition that occurs over a range of temperature due to the presence of impurities in the sample, the vaporization of water (indicating the presence of hydrophilic groups) and the crystalline nature of the materials [32]. The second event corresponds to an exothermic transition and was observed at $300^{\circ} \mathrm{C}$ for SCG, respectively, with an associated enthalpy change of $17.2 \mathrm{~J} / \mathrm{g}$. This transition is related to the thermal depolymerization and branching of the samples, occurring at temperature ranges varying between 265 and $330^{\circ} \mathrm{C}$ [38]. These are probably changes in hemicellulose. These transformations were described by Line et al. [32] are similar to those determined in the tested coffee samples. In tested SCG samples, glass transition was observed at a temperature of about $-2^{\circ} \mathrm{C}$.

FT-IR spectra of SCG showed a typical materials composed of polysaccharides and aromatic polymers (Fig. 3). Crystalline cellulose is an organic compound with a linear chain of several $\beta(1 \rightarrow 4)$ linked D-glucose units. Strong bands are visible on SCG FT-IR spectra at $1457 \mathrm{~cm}^{-1}$, $1374 \mathrm{~cm}^{-1}$ and $868 \mathrm{~cm}^{-1}$ was assigned to the $\beta$-linkage of cellulose. Based on the peak of $1457 \mathrm{~cm}^{-1}$ for cellulose, two peaks showed the existence of lipids or several acids in SCG. In the wave number range at $3000-3600 \mathrm{~cm}^{-1}$ a high intensity band is visible $\mathrm{OH}$ stretching in carboxylic acid or various sugars and amine groups in caffeine or proteins. Bands at $2920 \mathrm{~cm}^{-1}$ and $2849 \mathrm{~cm}^{-1}$ are attributed to asymmetric and symmetric stretching of $\mathrm{C}-\mathrm{H}$ bonds of methyl group in the caffeine molecule along with sugars [33]. These bands can also be associated with asymmetric and symmetric $\mathrm{C}-\mathrm{H}$ stretching in lipids [34]. The lipid is also associated with the band at $1736 \mathrm{~cm}^{-1}$, which was attributed to carbonyl vibration $(\mathrm{C}=\mathrm{O})$ in aliphatic ester or triglycerides [35]. The spectrum FT-IR the band at the $1510 \mathrm{~cm}^{-1}$ vibration is poorly visible. This vibration was due to $C=C$ stretching of aromatic ring in lignin or lipids [36]. Several peaks, $1245 \mathrm{~cm}^{-1}$ (C-O stretching), $1154 \mathrm{~cm}^{-1}$ (C-O-C asymmetric stretching) and $1027 \mathrm{~cm}^{-1}$ (C-O stretching), are attributed a great variety of monosaccharides together with diverse acids molecules, such as chlorogenic acid, caffeic acid and coumaric acid [37].

Images obtained by scanning electron microscopy present that the SCG particles are composed of thin 


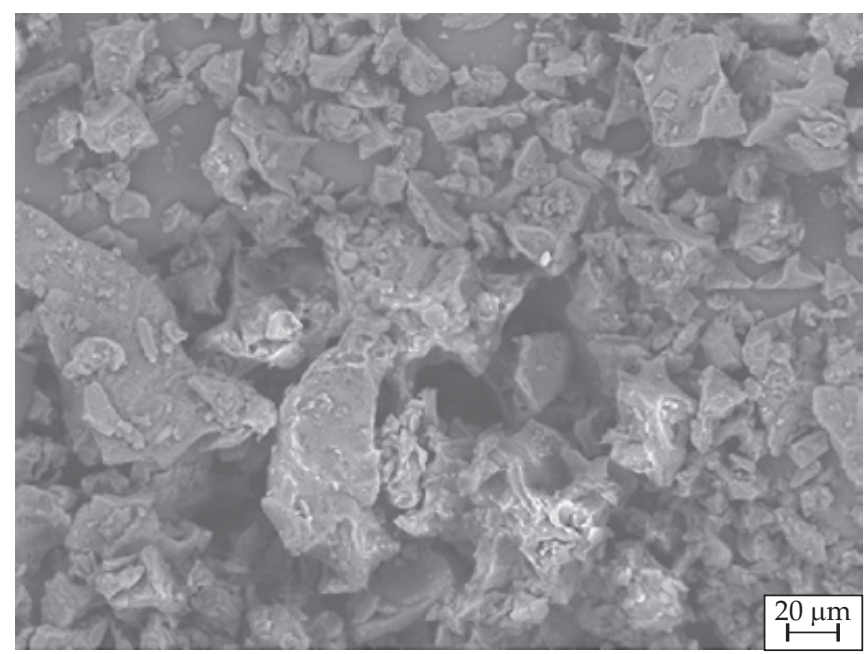

Fig. 4. Micrograph by scanning electron microscopy of spent coffee grounds particles; magnification $500 x$

sheets - petals (Fig. 4). In her work, Lina et al. [32] also stated that SCG is material with very low porosity.

The particle size of the filler in isopropanol was analyzed using a laser analyzer, and the results of particle size analysis are presented in Fig. 5. SCG particles have a size in the range $13-890 \mu \mathrm{m}$. The median particle size is $221 \mu \mathrm{m}$ (std dev. $165 \mathrm{um}$ ). Two maxima were observed on the curve with particle sizes of about $77 \mu \mathrm{m}$ and $344 \mu \mathrm{m}$.

\section{Characteristics of VPF foam and its SCG composites}

Addition of a filler causes a changes in the reaction kinetics, which was observed by analyzing the change in foam growth time $\left(t_{g}\right)$ ( Fig. 6).

As a result of this analysis, it was found that by adding $10 \mathrm{wt} \%$ of the filler, the $t_{g}$ value is clearly shortened, which can be associated with an increase in the number of pores, because the filler particles can act as additional pore germs. The process of nucleating gas bubbles can be modified, among others by using fillers, e.g. in the form of nanoparticles, which will act as hetero zips [38]. Thanks to the hetero nucleation process leading to the formation of gas bubbles, it is possible to obtain foam structures with reduced pore sizes [39]. As a result of the ana-

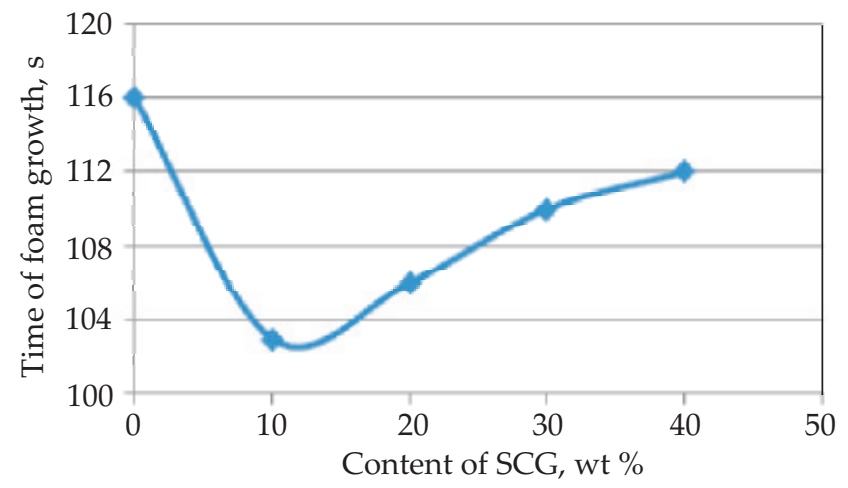

Fig. 6. Influence of the filler additionon the change in growth time $\left(t_{g}\right)$ of produced foams

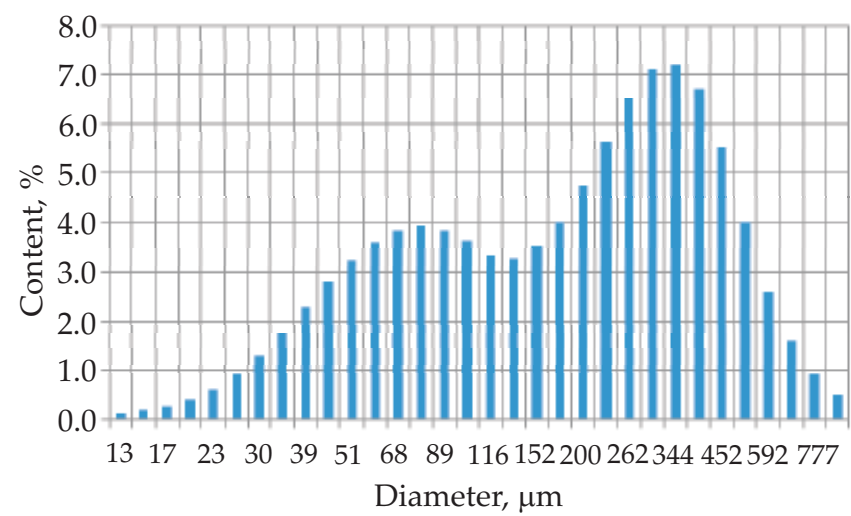

Fig. 5. SCG filler particle size distribution

lyzes it was found that used SCG filler contain approx. $3.6 \mathrm{wt} \%$ water. Water put into foam formulations significantly increases the demand for isocyanate. Therefore, it was analyzed how changes in the content of water added with the filler affect the change in the isocyanate index (INCO) of composites (Table 3).

$\mathrm{T}$ a b l e 3. Dependence of the isocyanate index on the amount of water added from SCG

\begin{tabular}{c|c|c|c|c|c}
\hline $\begin{array}{c}\text { Sample } \\
\text { name }\end{array}$ & VPF0 & VPF10 & VPF20 & VPF30 & VPF40 \\
\hline $\begin{array}{c}\text { Added } \mathrm{H}_{2} 0 \\
\text { wt } \%\end{array}$ & 0 & 0.36 & 0.72 & 1.08 & 1.44 \\
$\begin{array}{c}\text { Adjusted } \\
\text { NCO }\end{array}$ & 90 & 87 & 84 & 81 & 78 \\
\hline
\end{tabular}

During the analysis of foams, Krebs and Hubel [40] found that a decrease in INCO results in a decrease in the degree of crosslinking of VEPUR foams, a decrease in porosity and a slight increase in the growth time of these foams. In order to clarify whether similar changes caused the addition of SCG, foam growth time was analyzed (Fig. 6). Increasing the proportion of filler causes that the growth time of foams is longer, it also causes a decrease in INCO in foam formulations. By Krebs and Hubel should cause a slight increase in foam growth time, which was also observed in the tested foams. The reduction in growth time of VPF10 compared to foam without filler, may be due to the incorporation of minerals from SCG. Most often they are various metal compounds that can act as catalysts. Saunders and Frish [41] ranked metal compounds according to their activity as catalysts, starting with the most active in the following sequence: $\mathrm{Bi}, \mathrm{Pb}, \mathrm{Sn}, \mathrm{Ti}, \mathrm{Fe}, \mathrm{Sb}, \mathrm{U}, \mathrm{Cd}, \mathrm{Co}, \mathrm{Th}, \mathrm{Al}, \mathrm{Hg}$, Zn, $\mathrm{Ni}, \mathrm{Ce}, \mathrm{Mo}, \mathrm{V}, \mathrm{Cu}, \mathrm{Mn}, \mathrm{Zr}$.

The results presented in the paper Lin et al. [32] indicate that SCG contained large amounts of mineral compounds. Among the components mentioned in the analysis were significant amounts of iron, aluminum, manganese, zinc and cobalt compounds, which are catalysts for the reaction of $\mathrm{OH}$ and $\mathrm{NCO}$ groups.

In the foams presented in Fig. 7, a reduction in the pore size was observed, an increase in wall thickness 
a)

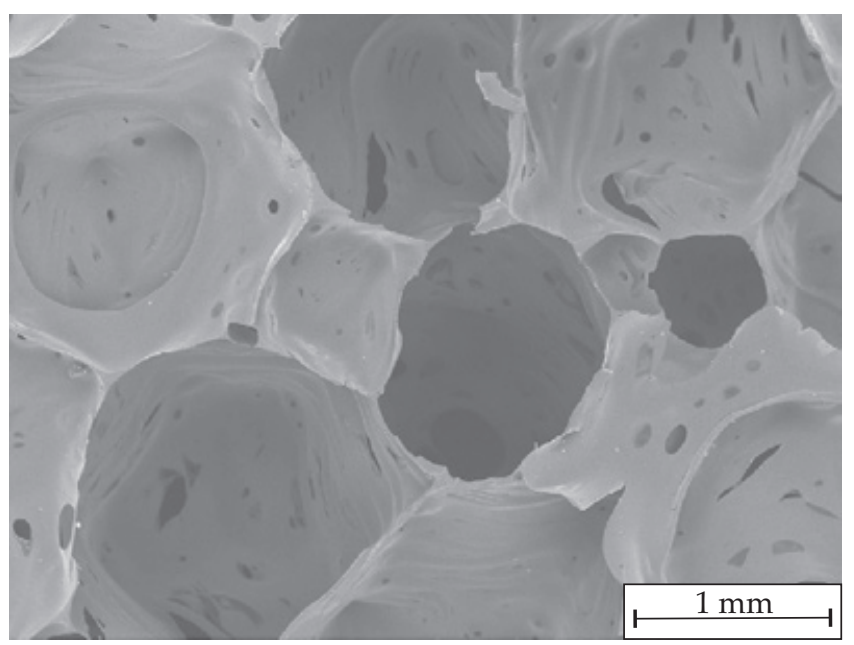

c)

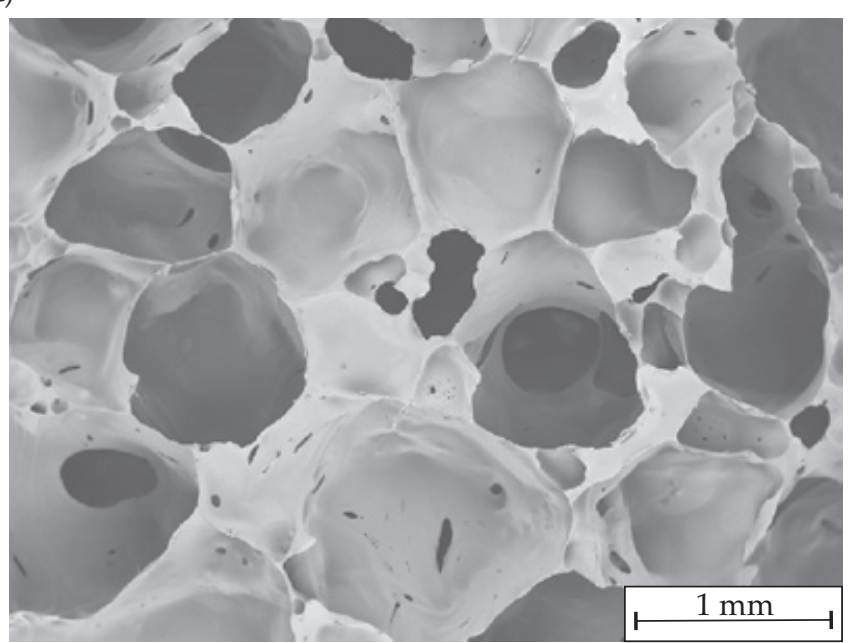

b)

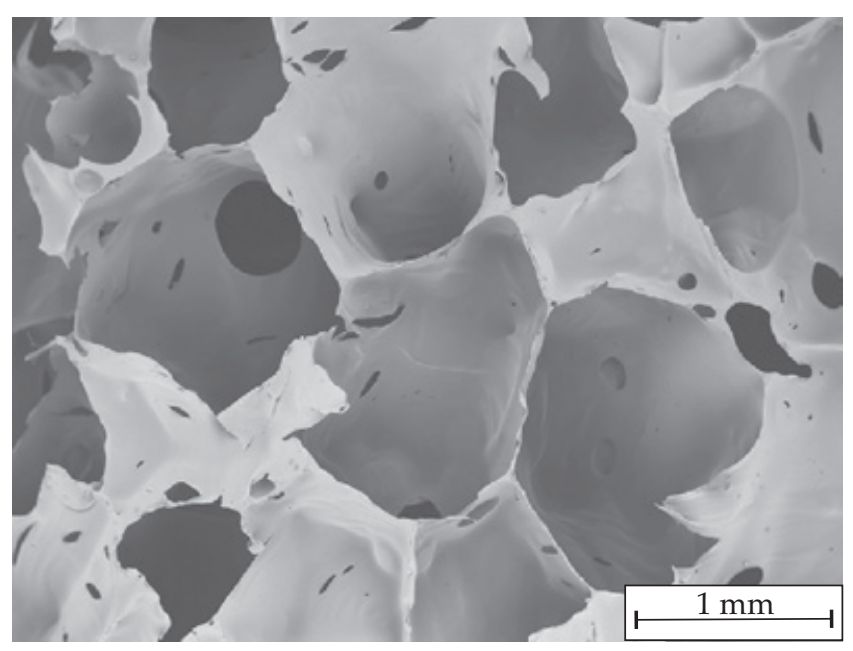

d)

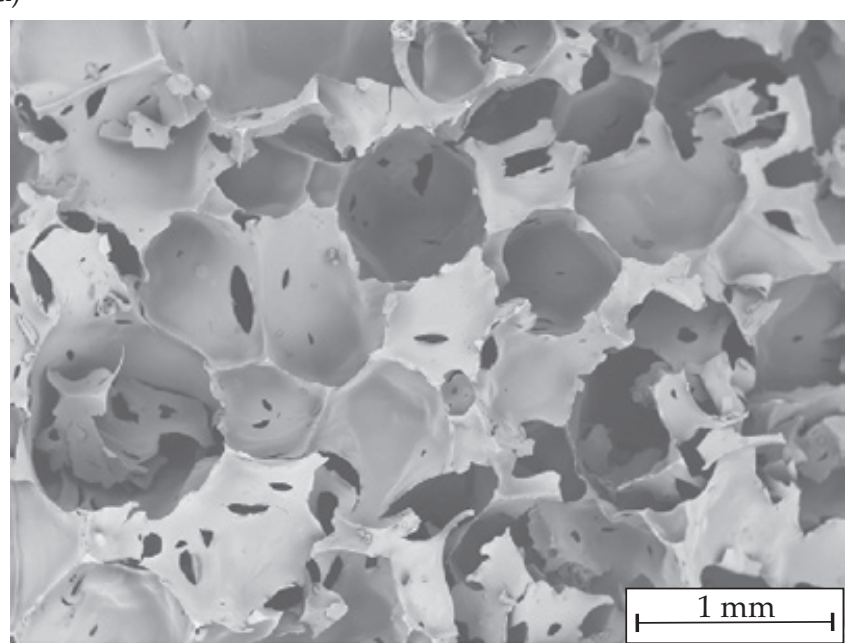

Fig. 7. SEM images of: a) VPF foam and its composites: b) 10 wt $\%$ of SCG, c) 30 wt $\%$ of SCG, d) 40 wt $\%$ of SCG

and increase in number of hole in the pore walls, these changes indicate a decrease in porosity in the analyzed materials along with an increase in the amount of filler introduced. These results are consistent with those presented by Krebs and Hubel [40], determining the effect of INCO on porosity.

FT-IR spectra were performed to describe the chemical structure of VPF foam and its SCG composites. Figure 8 compares the spectra of foam and its composite containing $40 \mathrm{wt} \%$ of SCG.

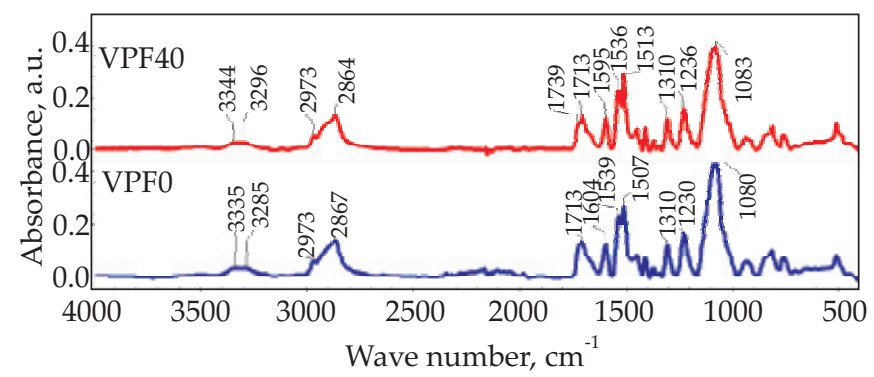

Fig. 8. FT-IR spectrum of the VPF0 and VPF40 foam
The spectra are representative of samples which are the subject of the article. In range of wave number 3300 $3500 \mathrm{~cm}^{-1}$ appear bands also from reaction substrates. Wave number $3335 \mathrm{~cm}^{-1}$ and $3285 \mathrm{~cm}^{-1}$ originates from stretching vibration, symmetrical and asymmetrical, assigned to $\mathrm{N}-\mathrm{H}$ bond. The band in the vicinity of wave number $3500 \mathrm{~cm}^{-1}$ is derived from the group -OH from water or unbound polyols. Clearly outlining a range of wave number $2867 \mathrm{~cm}^{-1}$ and $2970 \mathrm{~cm}^{-1}$ originates from stretching vibrations within groups $-\mathrm{CH}_{2}$ in the soft segments formed from polyols $[42,43]$. There was no band in the vicinity of wave number $2270 \mathrm{~cm}^{-1}$ attributable to the binding of $-\mathrm{NCO}$ derived from unreacted isocyanate [42]. In all the analyzed samples were also observed bands derived from bonds vibrations of $\mathrm{C}=\mathrm{O}\left(1708 \mathrm{~cm}^{-1}\right), \mathrm{C}=\mathrm{C}$ from aromatic ring $\left(1597 \mathrm{~cm}^{-1}\right)$ bending and deformation vibrations derived from $\mathrm{N}-\mathrm{H}$ bonds within $\mathrm{HNC}=\mathrm{O}(1538$ and $\left.1511 \mathrm{~cm}^{-1}\right), \mathrm{H}_{3} \mathrm{C}-\mathrm{C}\left(1458 \mathrm{~cm}^{-1}\right),-\mathrm{O}-\mathrm{CH}_{2}\left(1413 \mathrm{~cm}^{-1}\right)$ and $v_{\text {asym }}$ $\mathrm{CO} / \mathrm{sym}$ within the group -NCO-O (1234 and $\left.917 \mathrm{~cm}^{-1}\right)$ in $-\mathrm{C}-\mathrm{O}-\mathrm{C}-$ group [42]. In the range around $760 \mathrm{~cm}^{-1}$ the band represents a $\mathrm{C}-\mathrm{H}$ bond from the aromatic ring. 


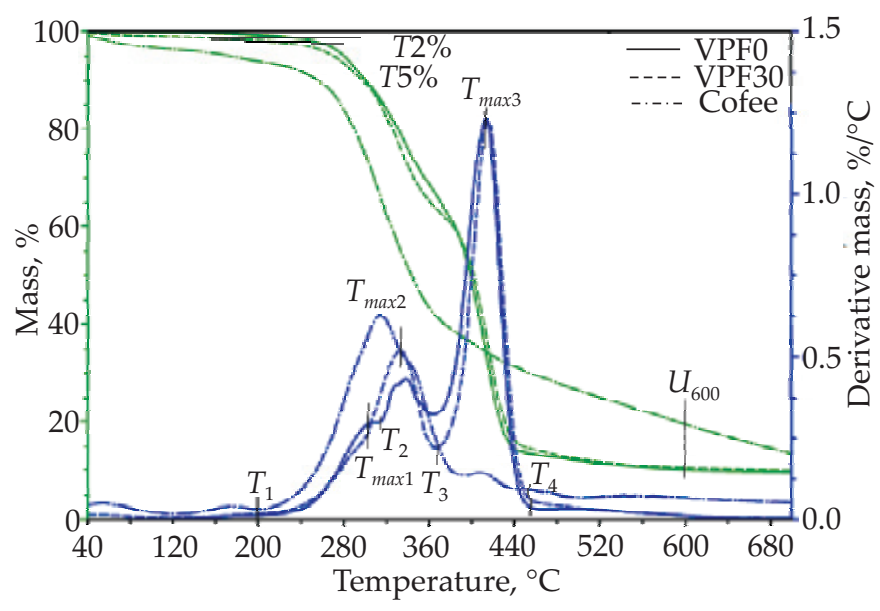

Fig. 9. Comparison of TGA and DTG of coffee, VPF0 and VPF30 curves

Thermogravimetric analysis was also carried out for the foams, the results are illustrated in Fig. 9.

On the basis of the TG thermogram curves, the temperature of $2 \%$ mass loss (T2\%), temperature of $5 \%$ mass loss $(\mathrm{T} 5 \%)$ and degradation residue at $600^{\circ} \mathrm{C}$ were determined.

However, on the basis of DTG curves, the temperature of the beginning and end of individual degradation stages $T_{i}$ and $T_{i+1}$, as well as the mass loss at the beginning and end of each stage $\left(m_{i}\right.$ and $\left.m_{i+1}\right)$ were determined, which allowed the determination of the change in mass during $\Delta m_{i}=\left(m_{i+1}-m_{i}\right)$. The maximum degradation rate $\left(v_{\max }\right)$ and the temperature at which the maximum degradation rate $\left(T_{\max }\right)$ of each stage was reached were also determined.
The course of the analysis is schematically presented in Fig. 9, and the results of the analysis for all foams are presented in Table 4. This table also indicates the tendency in change for each of the foam features.

The introduction of a filler causes a clear decrease in the $2 \%$ mass loss temperature associated with the loss of water and easily volatile substances contained in foams, and a $\mathrm{T} 5 \%$ temperature often considered as the onset temperature of polyurethane degradation. The more filler in the biocomposite, the lower the $T 5 \%$. The first stage of degradation of foam and biocomposites takes place in the range of 200 to $306 \pm 6^{\circ} \mathrm{C}$, the second stage of degradation ends at $369 \pm 1^{\circ} \mathrm{C}$, and the third ends at $455 \pm 3^{\circ} \mathrm{C}$. During the first stage of the decomposition process, the hard phase of foams degrade, probably most urethane bonds, and in composites additionally the degradation of hemicellulose. The mass loss at this stage decrease and change by approx. $9-14$ wt \%. The second stage of the process is associated with the degradation of the hard phase (urea bonds) and cellulose filler in composites. Mass loss at this stage may result from the distribution of urea bonds in the hard phase $[44,45]$. At this stage, the degradation rate in composites increases and the mass loss increases and change by approx. $19-25 \mathrm{wt} \%$.

The third degradation stage is related to the soft phase distribution of foams and the lignin in composites contained in the filler. In the third stage of degradation, the rate of degradation in composites significantly decreases with increasing amount of used filler. The mass loss in this stage decreases. After decomposition at $600^{\circ} \mathrm{C}$, as the

T a b 1 e 4. The results of the analysis of TG and DTG curves of foams

\begin{tabular}{|c|c|c|c|c|c|}
\hline Parameter/sample & VPF0 & VPF10 & VPF20 & VPF30 & VPF40 \\
\hline $\mathrm{T} 2 \%,{ }^{\circ} \mathrm{C}$ & 254 & 240 & 232 & 214 & 193 \\
\hline $\mathrm{T} 5 \%,{ }^{\circ} \mathrm{C}$ & 280 & 273 & 273 & 270 & 266 \\
\hline$T_{1},{ }^{\circ} \mathrm{C}$ & 200 & 200 & 200 & 200 & 200 \\
\hline$m_{1}, \%$ & 99.3 & 98.8 & 98.6 & 98.3 & 97.9 \\
\hline$T_{\max 1}{ }^{\circ} \mathrm{C}$ & 306 & 302 & 295 & 292 & 285 \\
\hline$v_{\max 1^{\prime}} \% /{ }^{\circ} \mathrm{C}$ & 0.30 & 0.30 & 0.22 & 0.22 & 0.25 \\
\hline $\mathrm{T}_{2},{ }^{\circ} \mathrm{C}$ & 313 & 312 & 303 & 299 & 304 \\
\hline$m_{2}, \%$ & 85.8 & 84.7 & 89.3 & 89.5 & 86.5 \\
\hline$\Delta m_{1}, \%$ & 13.8 & 14.1 & 9.3 & 8.8 & 11.4 \\
\hline$T_{\max 2}{ }^{\circ} \mathrm{C}$ & 338 & 340 & 338 & 332 & 334 \\
\hline$v_{\max 2^{\prime}} \% /{ }^{\circ} \mathrm{C}$ & 0.43 & 0.45 & 0.50 & 0.52 & 0.47 \\
\hline $\mathrm{T}_{3^{\prime}}{ }^{\circ} \mathrm{C}$ & 366 & 369 & 370 & 368 & 372 \\
\hline$m_{3^{\prime}} \%$ & 66.8 & 64.1 & 64.4 & 63.6 & 63.0 \\
\hline$\Delta m_{2^{\prime}} \%$ & 19.0 & 20.6 & 25.2 & 25.9 & 23.5 \\
\hline$T_{\max 3^{\prime}}{ }^{\circ} \mathrm{C}$ & 413 & 413 & 416 & 415 & 419 \\
\hline$v_{\max 3^{\prime}} \% /{ }^{\circ} \mathrm{C}$ & 1.23 & 1.28 & 1.25 & 1.23 & 1.14 \\
\hline$T_{4^{\prime}}{ }^{\circ} \mathrm{C}$ & 453 & 453 & 456 & 456 & 458 \\
\hline$m_{4} \%$ & 13.7 & 12.5 & 14.5 & 14.6 & 18.0 \\
\hline$\Delta m_{3^{\prime}} \%$ & 53.1 & 51.6 & 49.9 & 49,0 & 45.7 \\
\hline$U_{600^{\prime}} \%$ & 10.0 & 8.6 & 10.3 & 10.5 & 13.8 \\
\hline
\end{tabular}




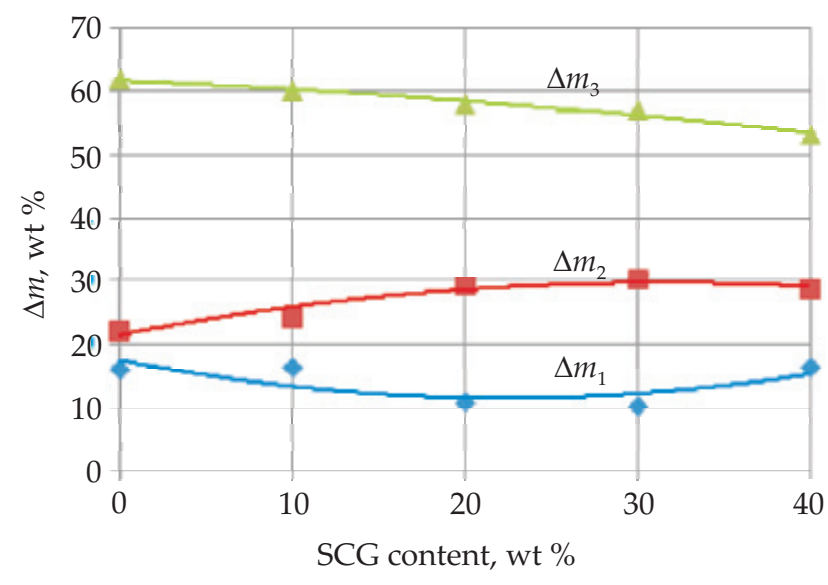

Fig. 10. Analysis of mass changes in subsequent stages of thermal degradation of VPF/SCG composites

filler increases, the amount of ash remaining after degradation of the filler increases.

Trends in mass changes at individual degradation stages are shown in Fig. 10. Addition to $30 \mathrm{wt} \%$ SCG causes a decrease in mass loss in the first stage of hard phase degradation and an increase in mass loss in its second stage. Such changes indicate that in the first stage of hard phase degradation urethane bonds break down and in the second stage urea bonds. Probably the share of urea bonds increases with increasing amounts of water introduced with filler. Mass changes associated with hard phase distribution overlap those associated with SCG distribution. The reduction in mass loss in the stage associated with the distribution of the soft phase of polyurethane is related with an increase in the filler content, which may be due to the large amount of ash remaining after SCG degradation.

Figure 11 presented DSC thermograms for unmodified foam, composite foams with SCGs, while Table 5 summarizes the results of the analysis.

a)

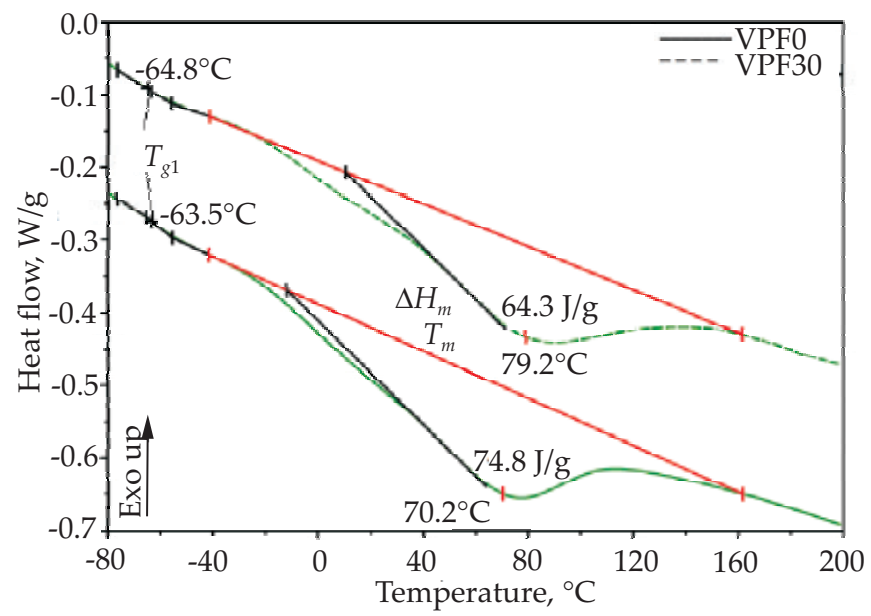

T a b l e 5. Results of the DSC analysis of examined materials

\begin{tabular}{c|c|c|c|c|c|c}
\hline Sample & $\begin{array}{c}T_{g 1} \\
{ }^{\circ} \mathrm{C}\end{array}$ & $\begin{array}{c}T_{d} \\
{ }^{\circ} \mathrm{C}\end{array}$ & $\begin{array}{c}\Delta H_{d} \\
\mathrm{~J} / \mathrm{g}\end{array}$ & $\begin{array}{c}T_{g 1^{\prime}} \\
{ }^{\circ} \mathrm{C}\end{array}$ & $\begin{array}{c}T_{g^{2}} \\
{ }^{\circ} \mathrm{C}\end{array}$ & $\begin{array}{c}T_{83} \\
{ }^{\circ} \mathrm{C}\end{array}$ \\
\hline VPF0 & -62 & 71 & 85.3 & -62 & -15 & 39 \\
VPF10 & -64 & 84 & 67.5 & -63 & -16 & 57 \\
VPF20 & -64 & 63 & 58.0 & -63 & -13 & 43 \\
VPF30 & -65 & 79 & 73.2 & -63 & -12 & 60 \\
VPF40 & -65 & 72 & 73.2 & -64 & -5 & 58 \\
\hline
\end{tabular}

The viscoelastic foams are made up of three phases: a soft phase, a phase composed of mixed flexible and rigid segments, and a hard phase [44]. During the first heating cycle, the occurrence was observed on thermograms of VPF foams the glass transition temperature $\left(T_{g 1}\right)$ and endothermic peaks associated with the change in order of mixed flexible and rigid segments and a hard phase $\left(T_{d^{\prime}} \Delta H_{d}\right)$. In the tested foam and composites with coffee, the glass transition temperature was observed in the soft phase at about $-64 \pm 1^{\circ} \mathrm{C}$, the temperature associated with the change in order in the phase in the range $63-84^{\circ} \mathrm{C}$ and changes the enthalpy in the range $58-85 \mathrm{~J} / \mathrm{g}$. During the second heating cycle, three glass transition transformations were observed. The first $T_{g 1^{1}}$ is associated with the vitrification of the soft phase of foams, the second $\left(T_{g 2}\right)$ with the vitrification of the mixture of flexible and rigid segments, and the third with the vitrification of the hard phase $\left(T_{83}\right)$.

Thermal effects associated with transformations in composite foams overlap with thermal effects occurring in the filler. This makes the determination of characteristic transformations difficult and may increase the error of their determination. The addition of the filler does not affect the change of $T_{g 1^{\prime}}$ the more filler the higher glass transition temperature of the mixture of flexible and rigid segments $T_{g^{2}}$, which increases from -16 to $-5^{\circ} \mathrm{C}$.

The glass transition temperature of the hard phase VPF0 is around $39^{\circ} \mathrm{C}$, the addition of filler causes a sig-

b)

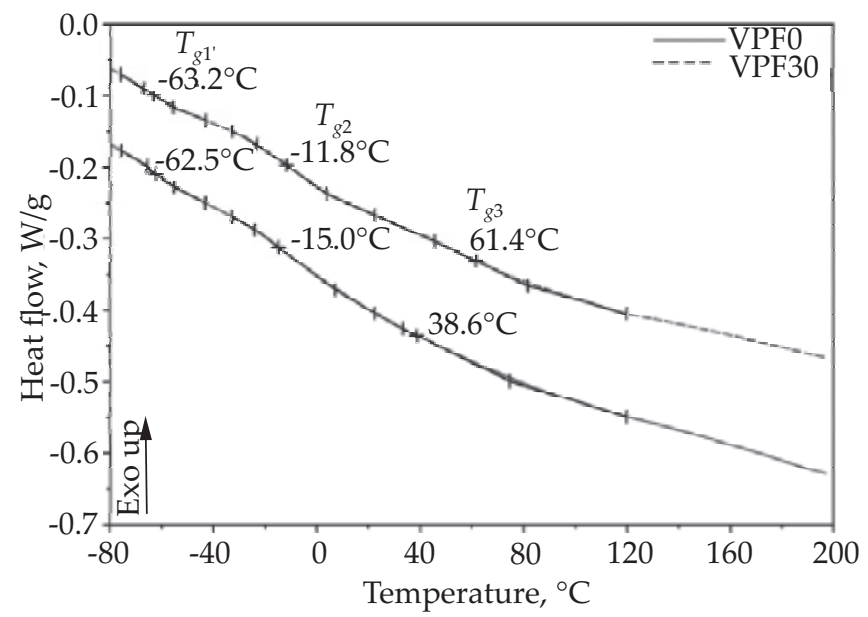

Fig. 11. Comparison of DSC thermograms of unmodified foam and composite foams with SCGs: a) first cycle of heating, b) second cycle of heating 
nificant increase in $T_{g 3}$ to a temperature in the range $43-60^{\circ} \mathrm{C}$. Changes in the micro- and macrostructure of foams caused by the addition of the filler affects changes in their properties. Table 6 summarizes the results of the apparent density $(D)$, calculations of the theoretical value of apparent density $\left(D_{t}\right)$, and differences between theoretical apparent density and apparent density $\left(D_{t}-D\right)$.

T a b l e 6. Apparent density of tested materials

\begin{tabular}{c|c|c|c}
\hline Materials & $\begin{array}{c}\text { Apparent } \\
\text { density } \\
D, \mathrm{~kg} / \mathrm{m}^{3}\end{array}$ & $\begin{array}{c}\text { Theoretical } \\
\text { apparent } \\
\text { density } \\
D_{t^{\prime}} \mathrm{kg} / \mathrm{m}^{3}\end{array}$ & $\begin{array}{c}D_{t}-D \\
\mathrm{~kg} / \mathrm{m}^{3}\end{array}$ \\
\hline VPF0 & $40.90 \pm 0.35$ & - & - \\
VPF10 & $41.09 \pm 0.26$ & 73.5 & 32.4 \\
VPF20 & $43.14 \pm 0.52$ & 107.5 & 64.4 \\
VPF30 & $50.90 \pm 1.41$ & 145.1 & 94.2 \\
VPF40 & $54.18 \pm 2.36$ & 178.5 & 124.3 \\
\hline
\end{tabular}

The apparent density increases with the amount of used filler. To explain the reason for these changes, the theoretical density of foams was calculated using the mixture rule for calculations. It was assumed that the density of the matrix in composite foams is equal to the density of VPF0 and the density of coffee is equal $365 \mathrm{~kg} / \mathrm{m}^{3}$ [46]. The theoretical apparent density of composite foams was higher than the apparent density, the difference between the density values for composite foams increased as the amount of filler increased. These results indicate that increased porosity of composite caused by the reaction of water introduced with the filler and NCO groups of isocyanate.

Low compression set of VPF is important, e.g. during transport, but also during use. Table 7 summarizes the results of determining the value of compression set for all tested samples. The VPF0 foams were significantly deformed as a result of the test, especially in the case of compression by $75 \%$ and $90 \%$ of the original height. After addition the filler, all foams have permanent deformations with a value below the permissible limit of $10 \%$.

Table 8 contains the values determined during the fourth foam compression cycle: comfort factor ( $S A G)$ and hardness parameter ( $F 40 \%)$. Increasing the proportion of filler in foams causes that the comfort factor increases

T a b l e 7. Results of measurements of permanent deformation after compression of foams

\begin{tabular}{c|c|c|c}
\hline \multirow{2}{*}{ Sample } & \multicolumn{3}{|c}{ The compression set $(\mathrm{CS})$} \\
\cline { 2 - 4 } & $22 \mathrm{~h}, 70^{\circ} \mathrm{C}, 50 \%$ & $22 \mathrm{~h}, 70^{\circ} \mathrm{C}, 75 \%$ & $22 \mathrm{~h}, 70^{\circ} \mathrm{C}, 90 \%$ \\
\hline VPF0 & $2.1 \pm 0.7$ & $10.0 \pm 0.9$ & $85.2 \pm 2.7$ \\
VPF10 & $1.1 \pm 0.7$ & $1.8 \pm 1.1$ & $2.8 \pm 1.1$ \\
VPF20 & $2.7 \pm 0.6$ & $3.8 \pm 1.5$ & $4.2 \pm 1.2$ \\
VPF30 & $1.4 \pm 0.8$ & $2.3 \pm 0.5$ & $2.8 \pm 0.8$ \\
VPF40 & $2.9 \pm 0.4$ & $3.2 \pm 1.0$ & $3.1 \pm 0.4$ \\
\hline
\end{tabular}

and the foam hardness decreases. Such changes in these properties are probably the result of a decrease in INCO due to the introduction of additional water into the reaction mixture. The hardness of the foams is not affected by the hardness of the filler particles.

$\mathrm{T}$ a $\mathrm{b}$ l e 8. Properties determined in the compression test of materials

\begin{tabular}{c|c|c}
\hline Materials & $\begin{array}{c}F 40 \% \\
\mathrm{~Pa}\end{array}$ & SAG \\
\hline VPF0 & $3.3 \pm 0.3$ & $2.1 \pm 0.1$ \\
VPF10 & $2.3 \pm 0.2$ & $2.1 \pm 0.1$ \\
VPF20 & $1.9 \pm 0.2$ & $2.2 \pm 0.1$ \\
VPF30 & $1.8 \pm 0.2$ & $2.6 \pm 0.2$ \\
VPF40 & $2.0 \pm 0.2$ & $2.7 \pm 0.2$ \\
\hline
\end{tabular}

Analysis of resistance to flame action in a cone calorimeter allowed to establish that the use of $20 \mathrm{wt} \%$ coffee particles reduces the maximum heat rate release $\left(H R R_{\max }\right)$ by approx. 12\% (Fig. 12). The total heat release (THR) of the composite decreases slightly, but clearly decrease by about $28 \%$ by mass loss rate (MLR). Such non-flammability properties of foam with the addition of $20 \mathrm{wt} \%$ SCG may be the result of an increase in the amount of carbon in the combusted material, as indicated by a significant amount of ash and SCG.

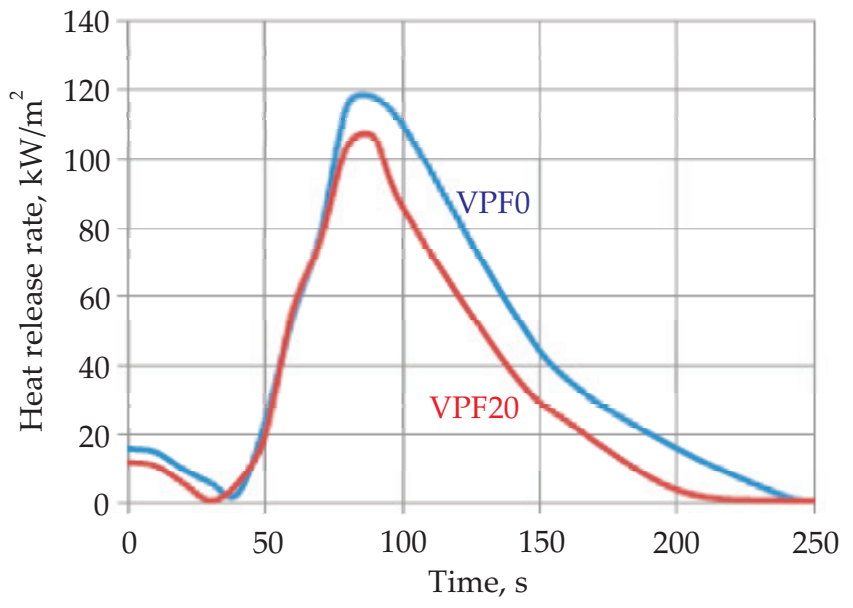

Fig. 12. Change in heat release rate as a function of time VPF0 and VPF20

\section{CONCLUSIONS}

The spent coffee grounds used to make composites are built like typical plant fillers made of hemicellulose, cellulose and lignin as well as secondary ingredients. The SCG contains: hemicellulose 42.7 wt $\%$, cellulose $15.5 \mathrm{wt} \%$, lignin $18.2 \mathrm{wt} \%$, about $3.6 \mathrm{wt} \%$ water and $1.1 \%$ of secondary ingredients. About $20 \%$ of the mass remains after degradation at $600^{\circ} \mathrm{C}$. The chemical structure of the coffee particles was confirmed by analysis using FT-IR and DSC. Coffee particles have sizes in the range $13-890 \mu \mathrm{m}$ and particle size of the filler is approx. 
$221 \mu \mathrm{m}$, they are characterized by low porosity. Addition of $10 \mathrm{wt} \%$ SCG filler into VPF foam reduces foam growth time by approx. $11 \%$. The reason for this change in the reaction kinetics is the use of filler with mineral components - many metal compounds that act as catalysts for the reaction of $-\mathrm{OH}$ and $-\mathrm{NCO}$ groups. Increasing the amount of filler increases the amount of water in the VPF reaction. This results in a lowering of the index of isocyanate in composites and, as a result, longer foam growth time. A larger amount of water also reduces the size of the pores, increases the wall thickness and of the ovals in the walls joining the pores.

These changes indicate a decrease in porosity in the analyzed materials resulting from a decrease in the index of isocyanate. The addition of a filler caused a change in the thermal characteristics and thermal degradation of composites. In foams with SCG filler, the temperature at which the release of volatile products begins and the degradation process begins decreases. However, the rate of degradation in the first stage of degradation associated with the hard phase degradation decreases, but the rate of degradation of the second phase of the hard phase degradation increases. Changes in the hard phase decomposition process result from changes caused by presence of additional water into the VPF formation environment.

The introduction of a filler reduces the degradation rate of the soft phase polyurethane foams.

The addition of a filler affected the change in apparent density of foams resulting from use a higher density filler and slight increase in foam porosity due to the formation of more $\mathrm{CO}_{2}$ as a result of the reaction of isocyanate with water. Compression set of foams after compression by $75 \%$ and $90 \%$ after the addition of SCG are extremely advantageously reduced.

The hardness of composites also decreased, which is significantly influenced by the change in the stiffness of joints between the pores in which the filler particles are embedded.

The comfort factor increased after adding SCG, which may be due to a decrease in the isocyanate index. The change in the isocyanate index is the result of introducing more water together with the filler. The flame retardancy of foams is the result of introducing more carbon with the filler. As a result, the heat release rate and smoke release rate are reduced.

\section{REFERENCES}

[1] Figueroa G., Homann T., Rawel H.: Austin Food Sciences 2016, 1, 1014.

[2] Campos-Vega R., Loarca-Pina G., Vergara-Castaneda H.A. et al.: Trends in Food Science \& Technology 2015, $45,24$. https://doi.org/10.1016/j.tifs.2015.04.012

[3] Cruz R., Cardoso M.M., Fernandes L. et al.: Journal of Agricultural and Food Chemistry 2012, 60, 7777. https://doi.org/10.1021/jf3018854
[4] Murthy P.S., Naidu M.M.: Resources, Conservation and Recycling 2012, 66, 45. https://doi.org/10.1016/j.resconrec.2012.06.005

[5] Caetano N.S., Silva V.F., Mata T.M.: Italian Association of Chemical Engineering 2012, 26, 267. https://doi.org/10.3303/CET1226045

[6] Park J., Kim B., Son J. et al.: Bioresource Technology 2018, 249, 494. https://doi.org/10.1016/j.biortech.2017.10.048

[7] Mussatto S.I., Carneiro L.M., Silva J.et al.: Carbohydrate Polymers 2011, 83, 368. https://doi.org/10.1016/j.carbpol.2010.07.063

[8] Fiol N., Escudero C., Villaescusa I.: Separation Science and Technology 2008, 43, 582. https://doi.org/10.1080/01496390701812418

[9] Roussos S., de los Angeles Aquiahuatl M., del Refugio Trejo-Hernandez M. et al:: Applied Microbiology and Biotechnology 1995, 42, 756. https://doi.org/10.1007/BF00171958

[10] Ballesteros L.F., Teixeira J.A., Mussatto S.L.: Food and Bioprocess Technology Provides 2014, 7, 3493. https://doi.org/10.1007/s11947-014-1349-z

[11] Farach A., Donangelo C.M.: Brazilian Journal of Plant Physiology 2006, 18, 1677. https://doi.org/10.1590/S1677-04202006000100003

[12] Mendes L., Mendes R.F., Tonoli G.H.D. et al.: Key Engineering Materials 2012, 517, 556.

https://doi.org/10.4028/www.scientific.net/ KEM.517.556

[13] Esquivel P., Jiménez V.M.: Food Research International 2012, 46, 488 . https://doi.org/10.1016/j.foodres.2011.05.028

[14] Mussatto S.I., Ballesteros L.F., Martins S. et al.: Separation and Purification Technology 2011, 83, 173. https://doi.org/10.1016/j.seppur.2011.09.036

[15] Arya M., Rao L.J.M.: Critical Reviews in Food Science and Nutrition 2007, 47, 51. https://doi.org/10.1080/10408390600550315

[16] Burniol-Figols A., Ceniana K., Skiadas I.V. et al.: Biochemical Engineering Journal 2016, 116, 54. https://doi.org/10.1016/j.bej.2016.04.025

[17] Wang H.M.D., Cheng Y.S., Huang C.H. et al.: Applied Biochemistry and Biotechnology 2016, 180, 753. https://doi.org/10.1007/s12010-016-2130-8

[18] Ryszkowska J.: „Materiały poliuretanowe wytwarzane z zastosowaniem surowców odnawialnych", Oficyna Wydawnicza Politechniki Warszawskiej, Warszawa 2019.

[19] Kintrup S., Treboux J.P., Mispreuve H.: Proceedings of the Polyurethanes Conference, Boston, Massachusetts, 8-10 October 2000, p. 91.

[20] Hager S., Skorpenske R., Triouleyre S. et al.: Journal of Cellular Plastics 2001, 37, 377. https://doi.org/10.1106/TQ0X-NBBV-RPD6-VWHH

[21] Krebs M., Hubel R.: "Highly Sophisticated Cell Opener for Viscoelastic Foam", Evonik Industries AG Nutrition \& Care Comfort \& Insulation, Essen Germany. 
https://www.pu-additives.com/.../Highly_ Sophisticate_Cell_Opener_for_Viscoelastic_Foam. pdf (10.04.2016).

https://www.pu-additives.com/product/pu-additives/downloads/highly_sophisticated_cell_opener_ for_viscoelastic_foam_paper.pdf

[22] Yao F., Wu Q., Lei Y. et al.: Polymer Degradation and Stability 2008, 93, 90.

https://doi.org/10.1016/j.polymdegradstab.2007.10.012

[23] Ramiah M.V.: Journal of Applied Polymer Science 1970, 14, 1323. https://doi.org/10.1002/app.1970.070140518

[24] Guimarães J.L., Frollini E., da Silva C.G. et al.: Industrial Crops and Products 2009, 30, 407. https://doi.org/10.1016/j.indcrop.2009.07.013

[25] Rowell R.M.: "Properties and performance of natural-fibre composites" in "Woodhead Publishing Series in Composites Science and Engineering" 2008, pp. 3-66.

[26] Faruk O., Bledzki A.K., Fink H.P. et al.: Progress in Polymer Science 2012, 37, 1552. https://doi.org/10.1016/j.progpolymsci.2012.04.003

[27] Gourier C., Le Duigou A., Bourmaud A. et al.: Composites Part A: Applied Science and Manufacturing 2014, 64, 159.

https://doi.org/10.1016/j.compositesa.2014.05.006

[28] Väisänen T., Haapala A., Lappalainen R. et al.: Waste Management 2016, 54, 62. https://doi.org/10.1016/j.wasman.2016.04.037

[29] Chun Y., Gun Ko Y., Do T. et al.: Colloids and Surfaces A: Physicochemical and Engineering Aspects 2019, 562, 392. https://doi.org/10.1016/j.colsurfa.2018.11.005

[30] Yang H., Yan R., Chen H. et al.: Fuel 2007, 86, 1781. https://doi.org/10.1016/j.fuel.2006.12.013

[31] Ribeiro J.P., Vicente E.D., Nunes M.I. et al.: Environmental Science and Pollution Research 2017, 24, 15270. https://doi.org/10.1007/s11356-017-9134-y

[32] Ballesteros L.F., Teixeira J.A., Mussatto S.I.: Food and Bioprocess Technology 2014, 7, 3493. https://doi.org/10.1007/s11947-014-1349-z

[33] Kemsley E.K., Ruault S., Wilson R.H.: Food Chemistry 1995, 54, 32. https://doi.org/10.1016/0308-8146(95)00030-M

[34] Craig A.P., Franca A.S., Oliveira L.S. et al.: Talanta 2014, 128, 393. https://doi.org/10.1016/j.talanta.2014.05.001

[35] Lyman D.J., Benck R., Dell S. et al.: Journal of Agricultural Food Chemistry 2003, 51, 3268. https://doi.org/10.1021/jf0209793

[36] Pandey K.K.: Journal of Applied Polymer Science 1999, 71, 1969.

h t t p s: // d o i.org / 10.1002 / ( S I C I ) 1097 4628(19990321)71:12<1969::AID-APP6>3.0.CO;2-D

[37] Clifford M.N., Kirkpatrick J., Kuhnert N. et al.: Food Chemistry 2008, 106, 379. https://doi.org/10.1016/j.foodchem.2007.05.081

[38] Saunders J.H., Hansen R.H.: "Plastic Foams", Marcel Dekker, New York, 1972, pp. 23-108.

[39] Saunders J.H., Hansen R.H.: "The Mechanism of Foam Formation" in "Plastic Foams, Part I", Marcel Dekker: New York, 1972, pp. 23-108.

[40] Krebs M., Hubel R.: “The Adjustment of Physical Properties of Viscoelastic Foam - the Role of Different Raw Materials", American Chemistry Council, 2016. https://www.pu-additives.com/product/pu-additives/downloads/adjustments-of-physical-properties. pdf.

[41] Saunders J.H., Frisch K.C.: "Polyurethanes: Chemistry and Technology. Chemistry", RE Krieger, 1987.

[42] Hatchett D.W., Kinyanju J.M., Sapochak L.: Journal of Cellular Plastics 2007, 43, 183. http://dx.doi.org/10.1177/0021955X07076665

[43] Zieleniewska M., Szczepkowski L., Krzyżowska M. et al.: Polimery 2016, 61, 807. http://dx.doi.org/10.14314/polimery.2016.807

[44] Bernardini J., Angullesi I., Coltelli M.B. et al.: Polymer International 2015, 64, 1235. https://doi.org/10.1002/pi.4905

[45] Demirci F., Yildirim K., Kocer H.B.: Journal of Applied Polymer Science 2018, 135, 45914. https://doi.org/10.1002/app.45914

[46] Ammerlaan T., Barrière V., Genest-Richard P. et al.: "Tales of a Forgotten Bioresource: The Recycling of Spent Coffee Grounds", Department of Bioresource Engineering, McGill University Montréal, Canada, 23.04.2012.

https://www.mcgill.ca/bioeng/files/bioeng/thomas_ violette_sandra_pascal_2012.pdf.

[47] Schnabel W.: "Polymer degradation. Principles and applications", Akademie-Verlag, Berlin 1981.

Received 7 II 2020 